\title{
HUBUNGAN ANTARA MOTIVASI KERJA DAN KEMAMPUAN KERJA DENGAN KINERJA PETUGAS REKAM MEDIS DI RUMAH SAKIT LAVALETTE MALANG
}

\author{
Viska Yolanda \\ Setyo Budiwanto \\ Septa Katmawanti \\ Fakultas Ilmu Keolahragaan Univesitas Negeri Malang \\ email: viskayolanda37@gmail.com
}

\begin{abstract}
Medical record services in hospitals has not fulfill the quality of good medical record. Based on Minimum Service Standards (SPM) of medical record in Lavalette Hospital in 2015 shows that overall indicator of SPM medical record has not reached the target as stated in Kepmenkes No. 129/Menkes/SK/II/2008. It is because performance of medical record officer in the Lavalette Hospital can be said that not good enough in its implementation. The factors that cause high low performance is an ability factor and motivation factor. This research aims to study the relationship between work motivation and work ability with performance of medical record officer at Lavalette Hospital. This method of research was explanatory survey. The subject of research was all medical record officers with number of people is 7. Collecting data using questionnaires, observation and interview sheets. Analysis of data using statistical test of Rank Spearman. Based on these results of research by comparing rho count value with rho table value $(\alpha=0.05)$ 0.786, shows that there is no significant relationship between work motivation and performance $(0.661<0.786)$ and there is a significant relationship between work ability and performance $(0.813>0.786)$.
\end{abstract}

Keywords: Work Motivation, Work Ability, Perfomance of Medical Record Officers

\begin{abstract}
Abstrak: Pelayanan rekam medis di rumah sakit masih belum memenuhi mutu rekam medis yang baik. Berdasarkan Standar Pelayanan Minimal (SPM) rekam medis Rumah Sakit Lavalette tahun 2015, menunjukkan bahwa keseluruhan indikator SPM rekam medis belum mencapai sasaran sesuai yang tercantum pada Kepmenkes No. 129/Menkes/SK/II/2008. Hal ini disebabkan karena kinerja petugas rekam medis di Rumah Sakit Lavalette masih kurang baik dalam pelaksanaannya. Faktor yang berhubungan dengan tinggi rendahnya kinerja adalah faktor kemampuan dan faktor motivasi. Penelitian ini bertujuan untuk mengetahui hubungan antara motivasi kerja dan kemampuan kerja dengan kinerja petugas rekam medis di Rumah Sakit Lavalette. Metode penelitian yang digunakan adalah penelitian survei explanatory. Subyek penelitian adalah seluruh petugas rekam medis yang berjumlah 7 orang. Pengumpulan data menggunakan kuesioner, lembar observasi dan wawancara. Analisis data yang digunakan adalah uji korelasi Rank Spearman. Berdasarkan hasil penelitian dengan membandingkan nilai rho hitung dengan nilai rho tabel $(\alpha=0,05) 0,786$ menunjukkan bahwa tidak ada hubungan yang signifikan antara motivasi kerja dengan kinerja $(0,661<0,786)$ dan ada hubungan yang signifikan antara kemampuan kerja dengan kinerja $(0,813>0,786)$.
\end{abstract}

Kata kunci: Motivasi Kerja, Kemampuan Kerja, Kinerja Petugas Rekam Medis 
Rumah Sakit merupakan tempat penyediaan layanan kesehatan untuk masyarakat. Menurut Undang-undang No. 44 Tahun 2009 menyebutkan bahwa rumah sakit adalah institusi pelayanan kesehatan yang menyelenggarakan pelayanan kesehatan perorangan secara paripurna yang menyediakan pelayanan rawat inap, rawat jalan, dan gawat garurat. Salah satu fungsi yang paling utama dari sebuah rumah sakit adalah menyediakan pelayanan pengobatan dan pemulihan kesehatan dengan kualitas tinggi kepada pasien. Saat ini banyak dari masyarakat menuntut rumah sakit memberikan pelayanan kesehatan yang lengkap. Salah satu pelayanan yang minimal wajib disediakan oleh rumah sakit menurut Kepmenkes No. 129/Menkes/SK/II/2008 mengenai

Standar Pelayanan Minimal (SPM) Rumah Sakit adalah pelayanan rekam medis.

Permenkes No. 269/Menkes/ Per/XII/2008 mendefinisikan rekam medis sebagai berkas yang berisikan catatan dan dokumen mengenai identitas pasien, hasil pemeriksaan, pengobatan, tindakan dan pelayanan lainnya yang telah diberikan kepada pasien. Rekam medis mempunyai sifat yang sangat rahasia karena isi dari rekam medis merupakan data penting yang berisi tentang data pribadi, penyakit yang diderita, riwayat penyakit dan diagnosis lainnya. Indikator mutu rekam medis yang baik menurut Huffman (1990) dalam Zebua (2009) adalah kelengkapan dokumen rekam medis atau isian resume medis, keakuratan, tepat waktu dan memenuhi persyaratan hukum.

Indikator mutu rekam medis yang masih belum terpenuhi dan menjadi permasalahan rekam medis di rumah sakit yaitu kelengkapan dokumen rekam medis dan ketepatwaktuan penyediaan rekam medis. Kelengkapan dokumen rekam medis dan ketepataan penyediaan rekam medis merupakan hal yang sangat penting karena berpengaruh terhadap proses pelayanan yang dilakukan petugas medis dan mempengaruhi kualitas dari suatu pelayanan. Dokumen rekam medis yang lengkap dan penyediaan berkas rekam medis yang tepat waktu berperan untuk menjaga kualitas mutu dari pelayanan kesehatan.

Berdasarkan Standar Pelayanan Minimal (SPM) Rekam Medis Rumah Sakit Lavalette tahun 2015 yang tercantum dalam Laporan Tahunan 2015 Rumah Sakit PTPN XI Lavalette Kota Malang, menunjukkan bahwa keseluruhan indikator SPM rekam medis belum mencapai target yaitu kelengkapan pengisian rekam medis 24 jam setelah selesai pelayanan yang seharusnya memiliki target $100 \%$ yaitu hanya mencapai $87 \%$, kelengkapan informed consent setelah mendapatkan informasi yang jelas yang seharusnya memiliki $100 \%$ yaitu hanya mencapai $94 \%$, waktu penyediaan dokumen rekam medis pelayanan rawat jalan yang seharusnya memiliki target $\leq 10$ menit yaitu masih melebihi target (19 menit), dan waktu penyediaan dokumen rekam medis pelayanan rawat inap yang seharusnya memiliki target $\leq 15$ menit yaitu masih melebihi target (16 menit).

Jika dilihat dari data SPM Rekam

Medis Rumah Sakit Lavalette di atas dibandingkan dengan Kepmenkes No. 129/Menkes/SK/II/2008 tentang SPM Rumah Sakit, maka pelayanan rekam medis di Rumah Sakit Lavalette Kota Malang pada tahun 2015 dikategorikan belum memenuhi SPM rekam medis rumah sakit.

Ketidaklengkapan dalam pengisian rekam medis dan penyediaan rekam medis yang lama dapat memberikan dampak yang tidak baik bagi proses pelayanan kesehatan kepada pasien, karena waktu untuk proses pendaftaran sampai dilakukan tindakan medis menjadi lama. Di samping itu, ketidaklengkapan pada riwayat penyakit terdahulu serta tindakan medis yang telah dilakukan sebelumnya tidak dapat dilakukan secara baik akibat tidak lengkapnya data pada rekam medis pasien. 
Masalah yang muncul dari ketidaklengkapan pengisian rekam medis hingga penyediaan rekam medis yanglama di Rumah Sakit Lavalette merupakan tanggung jawab dari petugas rekam medis. Hal ini disebabkan karena terdapat prosedur kerja pada Standar Prosedur Operasional (SPO) rekam medis rumah sakit yang tidak dijalankan sepenuhnya oleh petugas rekam medis. Dimana salah satu tugas dari petugas rekam medis menurut Permenkes No. 55 Tahun 2013 yaitu meneliti kelengkapan pengisian rekam medis agar dokumen rekam medis yang didata dapat menjadi informasi yang valid dan menurut Kepmenkes No. 129/Menkes/SK/II/ 2008 tentang SPM Rumah Sakit, salah satu tugas petugas rekam medis adalah menyediakan dokumen rekam medis rawat jalan dan rawat inap. Sehingga berdasarkan permasalahan tersebut dapat dikatakan bahwa kinerja petugas rekam medis di Rumah Sakit Lavalette masih kurang baik dalam pelaksanaannya dan dapat mempengaruhi mutu rekam medis.

Berdasarkan teori Keith Davis menyatakan bahwa faktor yang berhubungan dengan kinerja adalah faktor kemampuan (ability) dan faktor motivasi (motivation). Faktor kemampuan didasarkan atas potensi yang dimiliki oleh seorang dalam menjalankan pekerjaannya sedangkan faktor motivasi didasarkan atas kekuatan baik dari dalam maupun dari luar yang mendorong seseorang untuk mencapai kinerja yang diharapkan. Berdasarkan hasil penelitian dalam Jurnal yang berjudul Hubungan Kemampuan dan Motivasi dengan Kinerja Pegawai di Badan Kepegawaian Negara Pusat Jakarta oleh Hani dkk (2014) menyatakan bahwa kemampuan kerja pegawai memiliki hubungan yang tinggi dengan kinerja pegawai dengan koefisien korelasi sebesar 0,826 dan motivasi kerja pegawai memiliki hubungan yang sedang dengan kinerja pengawai dengan koefisien korelasi sebesar 0,440. Hal ini menunjukan bahwa motivasi kerja dan kemampuan kerja memiliki hubungan dengan kinerja pegawai, seperti halnya dengan kinerja petugas rekam medis di Rumah Sakit Lavalette yang kurang baik diduga terdapat hubungannya dengan motivasi kerja dan kemampuan kerja.

Berdasarkan latar belakang yang diuraikan di atas, maka penulis tertarik untuk mengetahui kinerja petugas rekam medis di Rumah Sakit Lavalette dan mengetahui hubungannya dengan motivasi kerja dan kemampuan kerja. Sehingga penulis dapat mewujudkan kegunaan dalam penelitian ini untuk memberikan masukan dan pertimbangan kepada Rumah Sakit Lavalette dalam peningkatan kinerja petugas rekam medis melalui motivasi kerja dan kemampuan kerja.

Motivasi kerja adalah dorongan yang tumbuh dalam diri seseorang, baik yang berasal dari dalam maupun luar dirinya untuk melakukan suatu pekerjaan dengan semangat tinggi yang bertujuan untuk mendapatkan hasil kerja sehingga mencapai kepuasan sesuai dengan keinginannya. Motivasi kerja dapat dibedakan menjadi dua bentuk yaitu motivasi intrinsik dan motivasi ekstrinsik. Motivasi intrinsik dapat diukur dengan indikator: pencapaian, pengakuan orang lain, tanggung jawab, peluang untuk maju, kemungkinan berkembang, dan pekerjaan itu sendiri (John dkk, 2006). Sedangkan motivasi ekstrinsik dapat diukur dengan indikator: gaji, keamanan kerja, kondisi kerja, prosedur kerja, mutu supervisi teknis, status, dan hubungan interpersonal (John dkk, 2006).

Kemampuan kerja adalah suatu kapasitas individu untuk mengerjakan berbagai tugas secara sungguh-sungguh dalam suatu pekerjaan. Untuk mengetahui seseorang karyawan mampu atau tidak dalam melaksanakan pekerjaannya dapat dlihat melalui beberapa indikator menurut Robbins (1998) dalam Farlen (2011) yaitu terdiri dari kesanggupan kerja, pendidikan, dan masa kerja.

Kinerja adalah hasil kerja nyata yang dicapai seseorang dalam 
melaksanakan tugas yang diberikan kepadanya sesuai dengan wewenang dan tanggung jawab masing-masing dalam rangka upaya mencapai tujuan organisasi. Keith Davis (1989) dalam Rahmatika (2014) menyatakan bahwa faktor-faktor yang berhubungan dengan tinggi rendahnya kinerja adalah faktor kemampuan (ability) dan faktor motivasi (motivation). Hal ini dapat dirumuskan seperti: Human Performance $=$ Ability + Motivation (Rahmatika, 2014). Secara psikologis, kemampuan karyawan terdiri dari kemampuan potensi (IQ) dan kemampuan reality (knowledge + skill). Artinya, pegawai yang memiliki IQ di atas rata-rata dengan pendidikan yang memadai untuk jabatannya dan terampil dalam mengerjakan pekerjaan seharihari, maka akan lebih mudah mencapai kinerja maksimal (Rahmatika, 2014). Keith Davis dalam Kadir dkk (2014) merumuskan kemampuan (ability) sebagai kapasitas dalam melaksanakan pekerjaan yang dipengaruhi oleh pengetahuan (knowledge) dan keterampilan (skill), sedangkan motivasi (motivation) dipengaruhi oleh faktor sikap (attitude) dan situasi. Ability dan motivation adalah kombinasi yang menghasilkan prestasi individu (human performance) atau kinerja individu (Kadir dkk, 2014).

Rekam medis menurut Permenkes No.269/Menkes/Per/XII/ 2008 adalah berkas yang berisikan catatan dan dokumen mengenai identitas pasien, hasil pemeriksaan, pengobatan, tindakan dan pelayanan lainnya yang telah diberikan kepada pasien. Seseorang yang bertugas untuk melakukan tugas pengolahan rekam medis di rumah sakit disebut dengan petugas rekam medis. Tugas yang dilakukan oleh petugas rekam medis yaitu terdiri dari penataan berkas rekam medis (assembling), pemberian kode (coding), pelaporan rumah sakit, korespondensi rumah sakit, penyimpanan, peminjaman, penyusutan dan pemusnahan rekam medis.

Tujuan dalam penelitian ini adalah untuk mengetahui hubungan antara motivasi kerja dan kemampuan kerja dengan kinerja petugas rekam medis di Rumah Sakit Lavalette Malang.

\section{METODE}

Metode penelitian yang digunakan adalah penelitian survei explanatory dengan pendekatan cross sectional. Variabel bebas dalam penelitian ini adalah motivasi kerja dan kemampuan kerja, sedangkan variabel terikat adalah kinerja petugas rekam medis. Subyek penelitian atau biasa disebut dengan responden penelitian adalah seluruh petugas rekam medis di Rumah Sakit Lavalette Malang yang berjumlah 7 orang. Pengumpulan data dalam penelitian ini menggunakan kuesioner, lembar observasi dan wawancara. Pengumpulan data dilaksanakan pada tanggal 26 Desember 2016 sampai dengan tanggal 7 Maret 2017. Analisis data yang digunakan adalah uji korelasi Rank Spearman.

\section{HASIL PENELITIAN}

Hasil penelitian terhadap penilaian tiap variabel yaitu motivasi kerja, kemampuan kerja, dan kinerja petugas rekam medis disajikan pada tabel berikut:

Tabel 1 Penilaian Motivasi Kerja Petugas Rekam Medis di Rumah Sakit Lavalette

\begin{tabular}{clccc}
\hline No & & Motivasi Kerja & Jumlah & Persentase (\%) \\
\hline 1 & Baik & & 1 & 14,3 \\
2 & Cukup & & 6 & 85,7 \\
3 & Kurang & & 0 & 0 \\
\hline & & Jumlah & 7 & 100 \\
\hline
\end{tabular}


Berdasarkan Tabel 1 di atas diketahui bahwa responden yang memiliki motivasi kerja yang baik terdapat 1 orang $(14,3 \%)$ dan responden yang memiliki motivasi kerja yang cukup sebanyak 6 orang $(85,7 \%)$.
Jika dilihat dari penjabaran sub variabel motivasi kerja yaitu motivasi intrinsik dan motivasi ekstrinsik, maka hasil penelitian dapat dilihat pada tabel berikut:

Tabel 2 Penilaian Motivasi Intrinsik Petugas Rekam Medis di Rumah Sakit Lavalette

\begin{tabular}{cllcc}
\hline No & & Motivasi Intrinsik & Jumlah & Persentase (\%) \\
\hline 1 & Baik & & 1 & 14,3 \\
2 & Cukup & & 5 & 71,4 \\
3 & Kurang & & 1 & 14,3 \\
\hline & & Jumlah & 7 & 100 \\
\hline
\end{tabular}

Berdasarkan Tabel 2 di atas diketahui bahwa responden yang memiliki motivasi intrinsik yang baik terdapat 1 orang $(14,3 \%)$, responden yang memiliki motivasi intrinsik yang cukup sebanyak 5 orang $(71,4 \%)$, dan responden yang memiliki motivasi intrinsik yang kurang terdapat 1 orang $(14,3 \%)$.

Tabel 3 Penilaian Motivasi Ekstrinsik Petugas Rekam Medis di Rumah Sakit Lavalette

\begin{tabular}{cllcc}
\hline No & & Motivasi Ekstrinsik & Jumlah & Persentase (\%) \\
\hline 1 & Baik & & 2 & 28,6 \\
2 & Cukup & & 5 & 71,4 \\
3 & Kurang & & 0 & 0 \\
\hline & & Jumlah & 7 & 100 \\
\hline
\end{tabular}

Berdasarkan Tabel 3 di atas diketahui bahwa responden memiliki motivasi ekstrinsik yang baik terdapat 2 orang $(28,6 \%)$ dan responden yang memiliki motivasi ekstrinsik yang cukup yaitu sebanyak 5 orang $(71,4 \%)$.

Tabel 4 Penilaian Kemampuan Kerja Petugas Rekam Medis di Rumah Sakit Lavalette

\begin{tabular}{clccc}
\hline No & & Kemampuan Kerja & Jumlah & Persentase (\%) \\
\hline 1 & Baik & & 3 & 42,9 \\
2 & Cukup & & 4 & 57,1 \\
3 & Kurang & & 0 & 0 \\
\hline & & Jumlah & 7 & 100 \\
\hline
\end{tabular}

Berdasarkan Tabel 4 di atas diketahui bahwa responden yang memiliki kemampuan kerja yang baik sebanyak 3 orang $(42,9 \%)$ dan responden yang memiliki kemampuan kerja yang cukup sebanyak 4 orang $(57,1 \%)$.

Tabel 5 Penilaian Kinerja Petugas Rekam Medis di Rumah Sakit Lavalette

\begin{tabular}{clccc}
\hline No & & Kinerja & Jumlah & Persentase (\%) \\
\hline 1 & Baik & & 7 & 100 \\
2 & Cukup & & 0 & 0 \\
3 & Kurang & & 0 & 0 \\
\hline & & Jumlah & 7 & 100 \\
\hline
\end{tabular}

Berdasarkan Tabel 5 di atas diketahui bahwa seluruh responden memiliki kinerja yang baik yaitu sebanyak 7 orang (100\%).
Hasil penelitian mengenai hubungan antarvariabel disajikan dalam tabel berikut: 


\section{Motivasi Kerja dengan Kinerja Petugas Rekam Medis}

Perhitungan uji korelasi Rank Spearman untuk melihat hubungan motivasi kerja dengan kinerja petugas rekam medis dapat dilihat pada Tabel 6 .

Tabel 6 Tabel Pembantu Perhitungan Uji Korelasi Rank Spearman Untuk Melihat Hubungan Motivasi Kerja dengan Kinerja Petugas Rekam Medis

\begin{tabular}{ccccccc}
\hline \multirow{2}{*}{ No } & \multirow{2}{*}{ Motivasi Kerja (X1) } & \multirow{2}{*}{ Kinerja $(Y)$} & X1 & Yank & \multirow{2}{*}{$\mathrm{D}$} & \multirow{2}{*}{$\mathrm{D}^{2}$} \\
\hline 1 & 67.86 & 92.31 & 6 & 2.5 & 3.5 & 12.25 \\
2 & 74.11 & 92.31 & 2 & 2.5 & -0.5 & 0.25 \\
3 & 86.61 & 96.30 & 1 & 1 & 0 & 0 \\
4 & 67.86 & 83.33 & 6 & 7 & -1 & 1 \\
5 & 67.86 & 91.67 & 6 & 5 & 1 & 1 \\
6 & 68.75 & 91.67 & 3.5 & 5 & -1.5 & 2.25 \\
7 & 68.75 & 3.5 & 5 & -1.5 & 2.25 \\
& & & & & $\sum \mathrm{D}^{2}$ & 19 \\
\hline
\end{tabular}

Perhitungan nilai rho hitung:

$$
\begin{aligned}
\text { rho } & =1-\frac{6 \sum D^{2}}{N\left(N^{2}-1\right)} \\
& =1-\frac{6\left(19^{2}\right)}{7\left(7^{2}-1\right)} \\
& =0.661
\end{aligned}
$$

Berdasarkan perhitungan uji korelasi Rank Spearman di atas untuk melihat hubungan motivasi kerja dengan kinerja diperoleh hasil koefisien korelasi sebesar 0.661. Jika dibandingkan dengan nilai rho tabel 0.786 , maka nilai koefisien korelasi lebih kecil dari nilai rho tabel yang berarti tidak signifikan. Hal ini menunjukkan tidak terdapat hubungan yang signifikan antara motivasi kerja dan kinerja petugas rekam medis di Rumah Sakit Lavalette Malang.

Untuk melihat hubungan motivasi intrinsik dan motivasi ekstrinsik dengan kinerja petugas rekam medis dapat dilihat sebagai berikut:

Tabel 7 Tabel Pembantu Perhitungan Uji Korelasi Rank Spearman Untuk Melihat Hubungan Motivasi intrinsik dengan Kinerja Petugas Rekam Medis

\begin{tabular}{ccccccc}
\hline \multirow{2}{*}{ No } & \multirow{2}{*}{ Motivasi Intrinsik $\left(\mathrm{X} 1_{\mathrm{a}}\right)$} & \multirow{2}{*}{ Kinerja $(\mathrm{Y})$} & $\mathrm{X} 1_{\mathrm{a}}$ & $\mathrm{Y}$ & $\mathrm{D}$ & \multirow{2}{*}{$\mathrm{D}^{2}$} \\
\hline 1 & 55.00 & 92.31 & 7 & 2.5 & 4.5 & 20.25 \\
2 & 70.00 & 92.31 & 2 & 2.5 & -0.5 & 0.25 \\
3 & 80.00 & 96.30 & 1 & 1 & 0 & 0 \\
4 & 65.00 & 83.33 & 3 & 7 & -4 & 16 \\
5 & 60.00 & 91.67 & 5 & 5 & 0 & 0 \\
6 & 62.50 & 91.67 & 4 & 5 & -1 & 1 \\
7 & 57.50 & 91.67 & 6 & 5 & 1 & 1 \\
& & & & & $\sum \mathrm{D}^{2}$ & 38.5 \\
\hline
\end{tabular}

Perhitungan nilai rho:

$$
\begin{aligned}
\text { rho } & =1-\frac{6 \sum D^{2}}{N\left(N^{2}-1\right)} \\
& =1-\frac{6\left(38.5^{2}\right)}{7\left(7^{2}-1\right)} \\
& =0.313
\end{aligned}
$$

Berdasarkan uji korelasi Rank Spearman di atas untuk melihat hubungan motivasi intrinsik kinerja diperoleh hasil koefisien korelasi sebesar 0.313. Jika dibandingkan dengan nilai rho tabel 0.786 , maka nilai koefisien korelasi lebih kecil dari nilai rho tabel yang berarti tidak signifikan. 
Hal ini menunjukkan tidak terdapat hubunganyang signfikan antara motivasi intrinsik dan kinerja petugas rekam medis di Rumah Sakit Lavalette.

Tabel 8 Tabel Pembantu Perhitungan Uji Korelasi Rank Spearman Untuk Melihat Hubungan Motivasi Ekstrinsik dengan Kinerja Petugas Rekam Medis

\begin{tabular}{|c|c|c|c|c|c|c|}
\hline \multirow{2}{*}{ No } & \multirow{2}{*}{ Motivasi Ekstrinsik $\left(\mathrm{X} 1_{\mathrm{b}}\right)$} & \multirow{2}{*}{ Kinerja (Y) } & \multicolumn{2}{|c|}{ Rank } & \multirow{2}{*}{$\mathrm{D}$} & \multirow{2}{*}{$\mathrm{D}^{2}$} \\
\hline & & & $\mathrm{X} 1_{\mathrm{b}}$ & $\mathrm{Y}$ & & \\
\hline 1 & 75.00 & 92.31 & 3.5 & 2.5 & 1 & 1 \\
\hline 2 & 76.39 & 92.31 & 2 & 2.5 & -0.5 & 0.25 \\
\hline 3 & 90.28 & 96.30 & 1 & 1 & 0 & 0 \\
\hline 4 & 69.44 & 83.33 & 7 & 7 & 0 & 0 \\
\hline 5 & 72.22 & 91.67 & 5.5 & 5 & 0.5 & 0.25 \\
\hline 6 & 72.22 & 91.67 & 5.5 & 5 & 0.5 & 0.25 \\
\hline \multirow[t]{2}{*}{7} & 75.00 & 91.67 & 3.5 & 5 & -1.5 & 2.25 \\
\hline & & & & & $\sum \mathrm{D}^{2}$ & 4 \\
\hline
\end{tabular}

Perhitungan nilai rho:

$$
\begin{aligned}
\text { rho } & =1-\frac{6 \sum D^{2}}{N\left(N^{2}-1\right)} \\
& =1-\frac{6\left(4^{2}\right)}{7\left(7^{2}-1\right)} \\
& =0.929
\end{aligned}
$$

Berdasarkan perhitungan uji korelasi Rank Spearman di atas untuk melihat hubungan motivasi ekstrinsik dengan kinerja diperoleh hasil koefisien korelasi sebesar 0.929. Jika dibandingkan dengan nilai rho tabel 0.786 , maka nilai koefisien korelasi lebih besar dari nilai rho tabel yang berarti signifikan. Hal ini menunjukkan terdapat hubungan yang signifikan antara motivasi ekstrinsik dan kinerja petugas rekam medis di Rumah Sakit Lavalette Malang.

\section{Kemampuan Kerja dengan Kinerja Petugas Rekam Medis}

Perhitungan uji korelasi Rank Spearman untuk melihat hubungan kemampuan kerja dengan kinerja petugas rekam medis dapat dilihat pada Tabel 9.

Tabel 9 Tabel Pembantu Perhitungan Uji Korelasi Rank Spearman Untuk Melihat Hubungan Kemampuan Kerja dengan Kinerja Petugas Rekam Medis

\begin{tabular}{ccccccc}
\hline \multirow{2}{*}{ No } & \multirow{2}{*}{ Kemampuan Kerja $(\mathrm{X} 2)$} & \multirow{2}{*}{ Kinerja $(\mathrm{Y})$} & \multicolumn{2}{c}{ Rank } & \multirow{2}{*}{$\mathrm{D}$} & \multirow{2}{*}{$\mathrm{D}^{2}$} \\
\hline 1 & 74.19 & 92.31 & 5 & 2.5 & 2.5 & 6.25 \\
2 & 83.87 & 92.31 & 2 & 2.5 & -0.5 & 0.25 \\
3 & 93.55 & 96.30 & 1 & 1 & 0 & 0 \\
4 & 67.74 & 83.33 & 7 & 7 & 0 & 0 \\
5 & 80.65 & 91.67 & 3 & 5 & -2 & 4 \\
6 & 74.19 & 91.67 & 5 & 5 & 0 & 0 \\
7 & 74.19 & 91.67 & 5 & 5 & 0 & 0 \\
& & & & & $\sum \mathrm{D}^{2}$ & 10.5 \\
\hline
\end{tabular}

Perhitungan nilai rho:

$$
\begin{aligned}
\text { rho } & =1-\frac{6 \sum D^{2}}{N\left(N^{2}-1\right)} \\
& =1-\frac{4\left(10.5^{2}\right)}{7\left(7^{2}-1\right)} \\
& =0.813
\end{aligned}
$$

Berdasarkan perhitungan uji korelasi Rank Spearman di atas untuk melihat hubungan kemampuan kerja dengan kinerja diperoleh hasil koefisien korelasi sebesar 0.813. Jika dibandingkan dengan nilai rho tabel 0.786 , maka nilai koefisien korelasi lebih besar dari nilai rho tabel yang berarti signifikan. Hal ini menunjukkan terdapat hubungan yang 
signfikan antara kemampuan kerja dan kinerja petugas rekam medis di Rumah Sakit Lavalette Malang.

\section{PEMBAHASAN}

\section{Hubungan Motivasi Kerja dengan Kinerja Petugas Rekam Medis}

Hasil penelitian menunjukkan tidak adanya hubungan antara motivasi kerja dengan kinerja petugas rekam medis. Jika dilihat dari sub variabel motivasi kerja, maka hasil penelitian menunjukkan bahwa adanya hubungan antara motivasi ekstrinsik dengan kinerja petugas rekam medis dan tidak adanya hubungan antara motivasi intrinsik dengan kinerja petugas rekam medis. Hasil penelitian ini didukung dengan penelitian Anggraini (2007) yang menyatakan bahwa tidak terdapat hubungan yang signifikan antara variabel motivasi intrinsik dengan kinerja, sedangkan terdapat hubungan secara signifikan antara variabel motivasi ekstrinsik dengan kinerja. Penelitian ini juga sejalan dengan penelitian Sagala dan Fatih (2012) yang menyatakan bahwa tidak ada hubungan antara motivasi dengan kinerja perawat.

Hasil penelitian ini tidak sejalan dengan teori dari Keith Davis (1989) dalam Rahmatika (2014) yang menyatakan bahwa salah satu faktor yang berhubungan dengan tinggi rendahnya kinerja adalah faktor motivasi (motivation).

Hasil penelitian mengenai motivasi kerja ini mendukung teori Maslow dalam Robbins dan Coulter (2010) yang mengatakan bahwa kebutuhan fisiologis dan keamanan merupakan tingkatan kebutuhan yang lebih rendah yang dipenuhi secara eksternal biasa disebut dengan motivasi/faktor ekstrinsik. Sedangkan kebutuhan sosial, penghargaan, dan aktualisasi diri merupakan tingkatan kebutuhan yang lebih tinggi yang dipenuhi secara internal biasa disebut dengan motivasi/faktor intrinsik. Kebutuhan fisiologis dan keamanan merupakan kebutuhan dasar yang harus terpenuhi lebih dulu secara substansial, barulah kemudian orang akan mencari pemenuhan kebutuhan yang lebih tinggi hierarkinya. Hasil penelitian ini juga mendukung teori dua faktor yang dapat dilihat dari pandangan Herzberg dalam implikasi manajerial, yang menyatakan bahwa tidak ada ketidakpuasan kerja, tidak ada kepuasan kerja (John dkk, 2006).

Jika dilihat dari beberapa teori dan penelitian yang dijelaskan di atas, maka dapat disimpulkan bahwa hasil penelitian ini menyatakan tidak adanya hubungan antara motivasi kerja dengan kinerja petugas rekam medis. Namun jika dilihat dari sub variabel motivasi kerja, motivasi ekstrinsik lebih memiliki hubungan yang signifikan dengan kinerja pegawai dibandingkan dengan motivasi intrinsik. Hal ini disebabkan karena tingkatan yang lebih rendah yaitu faktor ekstrinsik yang lebih dahulu dipenuhi sebelum tingkatan yang lebih tinggi yaitu faktor intrinsik. Hal ini berarti bahwa kebutuhan petugas rekam medis yang sudah terpenuhi adalah kebutuhan yang memiliki tingkatan yang lebih rendah yaitu faktor ekstrinsik yang dapat meningkatkan kinerja petugasnya. Untuk faktor intrinsik yang berada pada tingkatan yang lebih tinggi belum dipenuhi kebutuhannya sehingga tidak dapat meningkatkan kinerja petugas rekam medis.

\section{Hubungan Kemampuan Kerja dengan Kinerja Petugas Rekam Medis}

Hasil penelitian menunjukkan adanya hubungan yang signifikan antara kemampuan kerja dengan kinerja petugas rekam medis. Hasil penelitian ini sesuai dengan penelitian Wahyuningrum (2008) yang menyatakan bahwa terdapat hubungan signifikan antara variabel kemampuan kerja dengan kinerja pegawai. Jika kemampuan pegawai ditingkatkan maka kinerja pegawai juga meningkat. Sesuai juga dengan penelitian Perdana (2012) yang menyatakan bahwa terdapat hubungan yang signifikan antara variabel kemampuan kerja dengan kinerja denga 
koefisien korelasi sebesar 0.758 dan nilai signifikansi 0.000 . Begitu pula dengan penelitian Hani dkk (2014) yang menyatakan bahwa kemampuan kerja memiliki hubungan yang positif dan signifikan dengan kinerja pegawai.

Hasil penelitian ini mendukung teori dari Keith Davis (1989) dalam Rahmatika (2014) yang menyatakan bahwa salah satu faktor yang berhubungan dengan tinggi rendahnya kinerja adalah faktor kemampuan (ability). Secara psikologis, kemampuan karyawan terdiri dari kemampuan potensi (IQ) dan kemampuan reality (knowledge + skill). Artinya, pegawai yang memiliki IQ di atas rata-rata dengan pendidikan yang memadai untuk jabatannya dan keterampilan dalam mengerjakan pekerjaan, maka ia akan lebih mudah mencapai kinerja yang diharapkan.

Hasil penelitian ini juga mendukung teori dari Robbins (1998) dalam Farlen (2011:17) yang menyatakan bahwa tingkat kinerja pegawai akan sangat tergantung pada faktor kemampuan pegawai itu sendiri seperti pendidikan, kesanggupan kerja, dan masa kerja dimana semakin tinggi tingkat kemampuan kerja yang dimiliki oleh seseorang karyawan, maka kinerja karyawan di dalam perusahaan akan tinggi pula. Dengan demikian pendidikan, kesanggupan kerja, dan masa kerja yang rendah akan berdampak negatif pada kinerja pegawai.

Berdasarkan teori dan penelitian sebelumnya di atas dapat disimpulkan bahwa kemampuan kerja petugas rekam medis dapat menentukan kinerjanya. Dengan demikian semakin tinggi kemampuan kerja petugas rekam medis di Rumah Sakit Lavalette yang terdiri dari indikator pendidikan dan kesanggupan kerja dalam melaksanakan pekerjaannya maka semakin tinggi juga kinerjanya.

\section{KESIMPULAN}

Berdasarkan hasil penelitian dan pembahasan, maka dapat disimpulkan sebagai berikut:
1. Tidak terdapat hubungan yang signifikan antara motivasi kerja dengan kinerja petugas rekam medis di Rumah Sakit Lavalette Malang, dengan penjabaran sub variabel yang diteliti sebagai berikut: tidak terdapat hubungan yang signifikan antara motivasi intrinsik dengan kinerja petugas rekam medis di Rumah Sakit Lavalette Malang dan terdapat hubungan yang signifikan antara motivasi ekstrinsik dengan kinerja petugas rekam medis di Rumah Sakit Lavalette Malang.

2. Terdapat hubungan antara kemampuan kerja dengan kinerja petugas rekam medis di Rumah Sakit Lavalette Malang.

\section{SARAN}

Berdasarkan kesimpulan yang telah diperoleh, maka saran yang dapat diberikan adalah sebagai berikut:

\section{Bagi Petugas Rekam Medis}

1. Berdasarkan hasil uji korelasi Rank Spearmen, indikator tanggung jawab memiliki hubungan yang signifikan dengan kinerja petugas rekam medis, maka perlu dilakukan pengembangan sumber daya manusia melalui pendidikan dan pelatihan agar petugas rekam medis memahami akan pentingnya tanggung jawab terhadap pekerjaan melakukan pengolahan rekam medis.

\section{Bagi Rumah Sakit Lavalette Malang}

1. Perlu mempertahankan kebijakan rumah sakit terkait adanya jaminan keamanan kerja dan kondisi kerja yang baik, dengan menyediakan fasilitas yang mendukung dan memotivasi petugas rekam medis dalam melaksanakan pekerjaannya.

2. Perlu mempertahankan kebijakan pemberian gaji atau tunjangan kepada petugas rekam medis serta kejelasan status atau kedudukan petugas rekam medis agar petugas rekam medis lebih termotivasi dalam melaksanakan pekerjaannya.

3. Perlu mengembangkan prosedur kerja 
terkait kebijakan tugas/kegiatan kerja petugas rekam medis agar tidak adanya lempar tanggung jawab atau melimpahkan tugas kerja ke bagian lain sehingga petugas rekam medis dapat melaksanakan pekerjaan pengolahan rekam medis dengan lebih maksimal dan dapat meningkatkan kinerjanya.

4. Perlu melakukan penambahan sumber daya manusia yang memiliki latar belakang pendidikan yang sesuai dengan bidang rekam medis, serta perlu mengadakan pelatihan khusus rekam medis di Rumah Sakit Lavalette untuk meningkatkan kemampuan atau kompetensi petugas rekam medis karena selama ini belum ada pelatihan khusus mengenai rekam medis yang diadakan oleh pihak rumah sakit. Sehingga petugas rekam medis sering mengikuti pelatihan di luar rumah sakit.

\section{Bagi Peneliti Selanjutnya}

1. Peneliti yang akan melakukan penelitian selanjutnya, diharapkan penelitian ini dapat digunakan sebagai salah satu sumber data untuk penelitian selanjutnya dan dilakukan penelitian lebih lanjut berdasarkan faktor lainnya, variabel yang berbeda, jumlah sampel yang lebih banyak, tempat yang berbeda, dan tetap menggunakan sasaran penelitian yaitu petugas rekam medis.

\section{DAFTAR RUJUKAN}

Anggraini, S. S. 2007. Hubungan Motivasi dengan Kinerja Petugas Rekam Medis di Rumah Sakit Umum Daerah Dr. Djasamen Saragih Pematang Siantar. Tesis diterbitkan. Medan: Universitas Sumatera Utara.

Farlen, F. 2011. Pengaruh Motivasi Kerja dan Kemampuan Kerja Terhadap Kinerja Karyawan (Studi pada karyawan PT. Unite Tractors, Tbk Samarinda). Skripsi diterbitkan. Yogyakarta:
Universitas

Pembangunan

Nasional "Veteran".

Hani S., Nina W. \& Mustam M. 2014. Hubungan Kemampuan dan Motivasi dengan Kinerja Pegawai di Badan Kepegawaian Negara Pusat Jakarta (Studi Kasus di Direktorat Kompensasi Aparatur Sipil Negara). (Online), (http://download.portalgaruda.org), diakses 5 November 2016.

Ivancevich, John M., Konopaske, R., \& Matteson, M. T. 2006. Perilaku dan Manajemen Organisasi Edisi Ketujuh. Jakarta: Erlangga.

Kadir, A., Marnis \& Machasin. 2014. Pengaruh Ability, Motivasi dan Pengembangan Karir Terhadap Kinerja Karyawan Redaksi PT Riau Pos Intermedia Pekanbaru. Jurnal Ekonomi, (Online), 22 (2): 46, (https://ejournal.unri.ac.id), diakses 10 Februari 2017.

Keputusan Menteri Kesehatan Republik Indonesia No. 129 Tahun 2008 tentang Standar Pelayanan Minimal Rumah Sakit, (Online), (http://www.pelkesi.or.id), diakses 5 November 2016.

Peraturan Menteri Kesehatan Republik Indonesia No. 269 Tahun 2008 tentang Rekam Medis, (Online), (http://dinkes.surabaya.go.id), diakses 5 November 2016.

Peraturan Menteri Kesehatan Republik Indonesia No. 55 Tahun 2013 tentang Penyelenggaraan Pekerjaan Perekam Medis, (Online), (pelayanan.jakarta.go.id), diakses 25 November 2016.

Rahmatika, I. 2014. Pengaruh Kemampuan dan Motivasi Kerja Terhadap Kinerja Karyawan (Studi di BNI Syariah Cabang Bogor). Skripsi Diterbitkan. Jakarta: UIN Syariah Hidayatullah.

Robbins, S. P., \& Coulter, M. 2010. Manajemen Edisi Kesepuluh. Jakarta: Erlangga.

Rumah Sakit Lavalette. 2015. Laporan Tahunan 2015 Rumah Sakit PTPN XI Lavalette Kota Malang. 
Malang: PT Nusantara Sebelas Medika.

Sagala, N. S., \& Fathi, A. 2012. Motivasi dan Kinerja Perawat Pelaksana dalam Memberikan Asuhan Keperawatan di RSUP H. Adam Malik Medan, 1 (3): 19. (Online), (jurnal.usu.ac.id), diakses 2 April 2017.

Undang-undang No. 44 Tahun 2009 tentang Rumah Sakit, (Online), (www.depkes.go.id), diakses 2 November 2015.
Wahyuningrum. 2008. Hubungan Kemampuan, Kepuasan dan Disiplin Kerja dengan Kinerja Pegawai di Kecamatan Tanggungharjo Kabupaten Grobogan. Tesis diterbitkan. Semarang: Universitas Dipenogoro.

Zebua, J. 2009. Pengaruh Budaya Organisasi dan Insentif Terhadap Kinerja Staf Rekam Medik Rumah Sakit Umum Pusat H. Adam Malik Medan. Tesis diterbitkan. Medan: Universitas Sumatera Utara. 